\title{
One-step isolation of sappanol and brazilin from Caesalpinia sappan and their effects on oxidative stress-induced retinal death
}

\author{
Golam Mezbah Uddin ${ }^{1,3}$, Chul Young Kim², Donghwa Chung ${ }^{3}$, Kyung-A Kim ${ }^{1}$ E Sang Hoon Jung ${ }^{1, *}$ \\ ${ }^{1}$ Natural Products Research Center, Korea Institute of Science and Technology (KIST) Gangneung Institute, Gangneung 201-340, \\ ${ }^{2}$ College of Pharmacy, Hanyang University, Ansan 426-791, ${ }^{3}$ Department of Marine Food Science and Technology, Gangneung-Wonju \\ National University, Gangneung 210-702, Korea
}

\begin{abstract}
Caesalpinia sappan is a well-distributed plant that is cultivated in Southeast Asia, Africa, and the Americas. C. sappan has been used in Asian folk medicine and its extract has been shown to have pharmacological effects. Two homoisoflavonoids, sappanol and brazilin, were isolated from $C$. sappan by using centrifugal partition chromatography (CPC), and tested for protective effects against retinal cell death. The isolated homoisoflavonoids produced approximately 20-fold inhibition of $\mathrm{N}$-retinylidene- $\mathrm{N}$-retinyl-ethanolamine (A2E) photooxidation in a dose-dependent manner. Of the 2 compounds, brazilin showed better inhibition $\left(197.93 \pm 1.59 \mu \mathrm{M}\right.$ of $\left.\mathrm{IC}_{50}\right)$. Cell viability tests and $\mathrm{Pl} / \mathrm{Hoechst} 33342$ double staining method indicated that compared to the negative control, sappanol significantly attenuated $\mathrm{H}_{2} \mathrm{O}_{2}$-induced retinal death. The compounds significantly blunted the up-regulation of intracellular reactive oxygen species (ROS), and sappanol inhibited lipid peroxidation in a concentration-dependent manner. Thus, both compounds represent potential antioxidant treatments for retinal diseases. [BMB Reports 2015; 48(5): 289-294]
\end{abstract}

\section{INTRODUCTION}

Retinal ganglion cells (RGC) are one of the types of cells that make up the retina. The gradual loss of RGC is involved in the pathophysiology of glaucoma (1). In glaucoma treatment, reduction of elevated intraocular pressure (IOP) does not always diminish the progression of glaucoma. Proper understanding of

${ }^{*}$ Corresponding author. Tel: +82-33-650-3653; Fax: +82-33-6503679; E-mail: shjung507@gmail.com

http://dx.doi.org/10.5483/BMBRep.2015.48.5.189

Received 3 September 2014, Revised 19 September 2014, Accepted 19 September 2014

Keywords: Antioxidant, Caesalpinia sappan, Centrifugal partition chromatography, Homoisoflavonoids, $\mathrm{N}$-retinylidene- $\mathrm{N}$-retinyl-ethanolamine (A2E) photooxidation the mechanisms behind RGC death and neuroprotection is crucial for the development of new effective treatments (2).

Oxidative stress has been shown to lead to RGC cell death and can be a primary cause of glaucoma (3). The proposed connection between oxidative stress and neuroprotection indicates the potential for regulation of the antioxidant defense system to protect against RGC death, which is a major element in the pathogenesis of glaucoma $(4,5)$.

Light is necessary for vision, but photons from the visible region can be absorbed by cellular chromophores and lead to cell death owing to imbalanced ROS production $(6,7)$. N-retinylidene- $N$-retinyl-ethanolamine (A2E) is a major component of lipofuscin, which accumulates with age on the retinal pigment epithelium (RPE) layer, and is considered a blue light-absorbing retinal chromophore that can mediate retinal damage. The phototoxic injurious effect of blue light on RPE can cause secondary changes in other retinal cells that can lead to retinal diseases (8).

Natural sources with various properties, especially anti-oxidant effects, have been suggested to prevent and treat neurodegenerative diseases such as glaucoma (9). Among the isolation techniques used to extract active ingredients from natural sources, CPC is an effective choice because of its large scale elution, wide variety of possible solvents, ability to use small amounts of solvents, and relatively quick one-step process (10).

Caesalpinia sappan (Leguminosae) is well distributed and cultivated in Southeast Asia, Africa, and the Americas. It is a hardwood with anti-bacterial, anti-inflammatory, emmenagogue, and analgesic properties that have led to its use in Asian folk medicine (11). The antioxidant properties of C. sappan heartwood extract have been showed previously in both in vitro and in vivo models (12). Because of the numerous biological effects of C. sappan, especially its antioxidant effects, in this study we isolated and identified compounds from this medicinal plant using centrifugal partition chromatography (CPC), and evaluated their ability to inhibit oxidative stress-induced retinal cell death. Another potential mechanism of retinal cell damage was evaluated by testing the capacity of the isolated

ISSN: 1976-670X (electronic edition)

Copyright (C) 2015 by the The Korean Society for Biochemistry and Molecular Biology

c) This is an open-access article distributed under the terms of the Creative Commons Attribution Non-Commercial License (http://creativecommons.org/licenses/by-nc/4.0) which permits unrestricted non-commercial use, distribution, and reproduction in any medium, provided the original work is properly cited. 
compounds to inhibit A2E photooxidation.

\section{RESULTS AND DISCUSSION}

\section{Isolation of sappanol and brazilin using CPC}

Separation of natural products using CPC is dependent on the partitioning behaviors of the target compounds between $2 \mathrm{im}$ miscible two-phase solvents that are used as a mobile phase and a stationary phase. In order to choose a suitable two-phase solvent system, several two-phase solvent systems were tested and their partition coefficients ( $\mathrm{K}$ values) were calculated. Using the selected solvent system (ethyl acetate:acetonitrile: water, 1:1:2, v/v), the ethyl acetate-soluble material (350 mg) was subjected to CPC and separated. As shown in Fig. 1A, peaks were separated very well in the CPC elution chromatogram, and 2 homoisoflavonoids were isolated, as shown in Fig. 1B and 1C. The isolated homoisoflavonoids were determined to be sappanol and brazilin using NMR data (Fig. 1D).

\section{Effects of sappanol and brazilin on A2E photooxidation}

Sappanol and brazilin isolated from C. sappan were tested for their effects on A2E photooxidation, and results are shown in Table 1. The photooxidation of $\mathrm{A} 2 \mathrm{E}$ is reflected by the reduced content of A2E in a sample after $450 \mathrm{~nm}$ illumination. Irradiation of $\mathrm{A} 2 \mathrm{E}$ in the absence of the isolated compounds caused a substantial decrease in the absorbance of the $\mathrm{A} 2 \mathrm{E}$ peak, such that levels were approximately $5 \%$ of those of non-irradiated controls. The loss of A2E was diminished in the presence of sappanol and brazilin in a concentration-dependent manner.

Lutein, zeaxanthin, and meso-zeaxanthin accumulate in the retina as yellowish pigments. The presence of lutein is considered to be responsible for retinal diseases such as age-related macular degeneration and cataract, but also protects the eye from light. The low dietary availability of lutein has led to its consumption as a supplement (13). To study the effects of homoisoflavonoids on A2E photooxidation, they were compared with lutein.

During aging, A2E accumulates over the retinal pigment epithelium, and has been implicated in the pathogenesis of retinal disorders. Increased sensitivity of the retinal cells to visible light due to photooxidation is a concern in age-related macular degeneration (14). In this study, homoisoflavonoids inhibited A2E photooxidation in a dose-dependent manner. Levels of $\mathrm{A} 2 \mathrm{E}$ in irradiated samples in the presence of the isolated compounds were more than 20-fold higher than in the absence of these compounds. Compared to sappanol, brazilin showed better inhibition of A2E photooxidation (Table 1). Thus, brazilin can be considered to be a candidate for further study as a prospective treatment for retinal diseases.

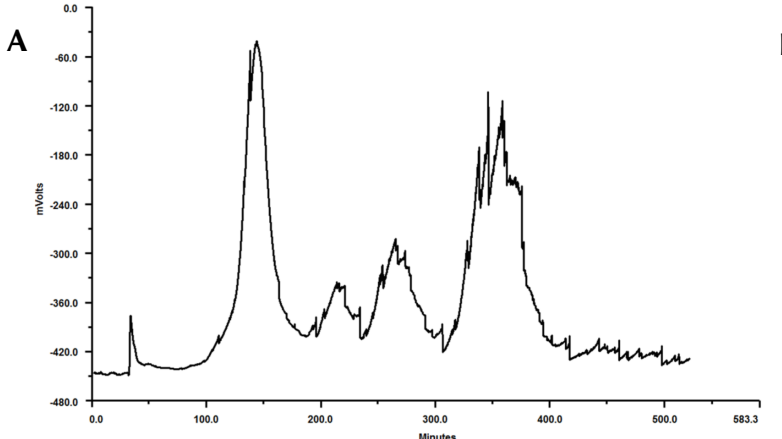

C

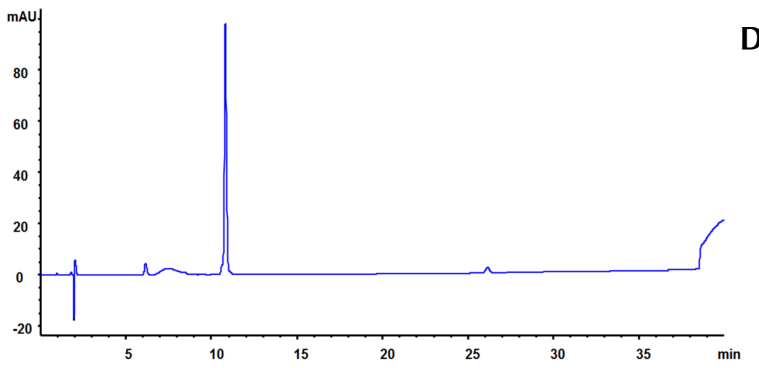

B

D

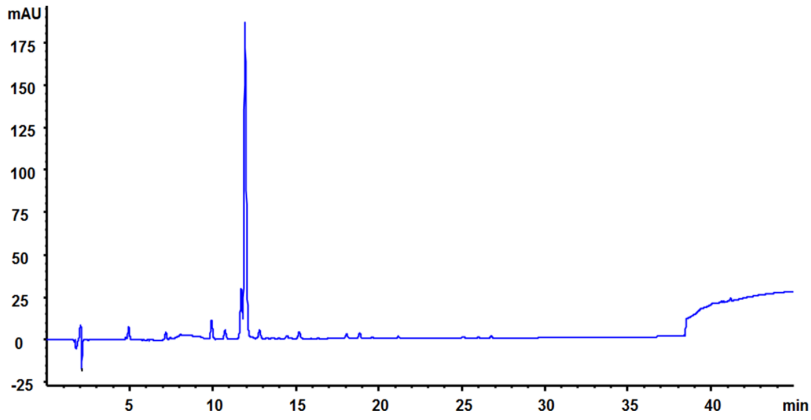<smiles>Oc1ccc2c(c1)OCC(O)(Cc1ccc(O)c(O)c1)[C@H]2O</smiles><smiles>Oc1ccc2c(c1)OCC1(O)Cc3cc(O)c(O)cc3[C@H]21</smiles>

Brazilin

Fig. 1. CPC separation (A) of the crude extract from Caesalpinia sappan. Solvent system: Ethyl Acetate : Acetonitrile: Water (1:1:2, v/v); flow-rate of the mobile phase, $2.0 \mathrm{ml} / \mathrm{min}$; revolution speed, $800 \mathrm{rpm}$; sample size, $350 \mathrm{mg}$; injection volume, $5 \mathrm{ml}$; detection wavelength, $280 \mathrm{~nm}$; retention of the stationary phase, 60\%; Peaks III and V in the CPC chromatogram correspond to sappanol (B) and brazilin (C), respectively. Chemical structures of isolated compounds from C. sappan (D). 
Table 1. The effect of different concentrations of compounds isolated from C. sappan on reduction of A2E photooxidation and inhibition of lipid peroxidation

\begin{tabular}{|c|c|c|c|c|c|c|c|}
\hline \multirow{2}{*}{ Sample } & \multicolumn{3}{|c|}{ Photochem* } & \multirow{2}{*}{ Sample } & \multicolumn{3}{|c|}{ Lipid Peroxidation** } \\
\hline & $\begin{array}{c}\text { Concentration } \\
\qquad(\mu \mathrm{M})\end{array}$ & $\begin{array}{c}\text { Inhibition } \\
(\%)\end{array}$ & $\begin{array}{l}\mathrm{IC}_{50} \\
(\mu \mathrm{M})\end{array}$ & & $\begin{array}{c}\text { Concentration } \\
(\mu \mathrm{g} / \mathrm{ml})\end{array}$ & $\begin{array}{c}\text { Inhibition } \\
(\%)\end{array}$ & $\begin{array}{l}\mathrm{IC}_{50} \\
(\mu \mathrm{M})\end{array}$ \\
\hline \multirow[t]{4}{*}{ Sappanol } & 400 & 58.78 & $316.14 \pm 3.38$ & EGCG & 1 & $82.91 \pm 2.50$ & 0.50 \\
\hline & 200 & 38.11 & & & 0.5 & $62.22 \pm 4.35$ & \\
\hline & 100 & 21.62 & & & 0.25 & $39.14 \pm 8.62$ & \\
\hline & 50 & 10.92 & & & 0.125 & $24.86 \pm 3.03$ & \\
\hline \multirow[t]{4}{*}{ Brazilin } & 400 & 68.01 & $197.93 \pm 1.59$ & & 0.0625 & $18.99 \pm 2.41$ & \\
\hline & 200 & 50.49 & & & 0.03125 & $12.74 \pm 3.73$ & \\
\hline & 100 & 32.68 & & Sappanol & 10 & $56.49 \pm 1.91$ & 8.59 \\
\hline & 50 & 20.07 & & & 5 & $33.09 \pm 4.86$ & \\
\hline \multirow[t]{4}{*}{ Lutein } & 200 & 86.49 & - & & 2.5 & $22.85 \pm 4.19$ & \\
\hline & & & & & 1.25 & $15.44 \pm 3.54$ & \\
\hline & & & & & 0.625 & $12.09 \pm 1.05$ & \\
\hline & & & & & 0.3125 & $9.95 \pm 3.85$ & \\
\hline
\end{tabular}

*Sappanol and brazilin reduce A2E photooxidation. The photooxidation of A2E is reflcted in the reduced content of A2E in a sample after $450 \mathrm{~nm}$ illumination. The loss of A2E was diminished in the presence of sappanol and brazilin at the indicated concentrations. Mean \pm S.E.M. of four experiments. ${ }^{* *}$ The effect of different concentrations of sappanol on inhibition of lipid peroxidation induced by sodium nitropruside (SNP) in rat forebrain homogenates. Results are means values \pm S.E.M. of three independent experiments.

A

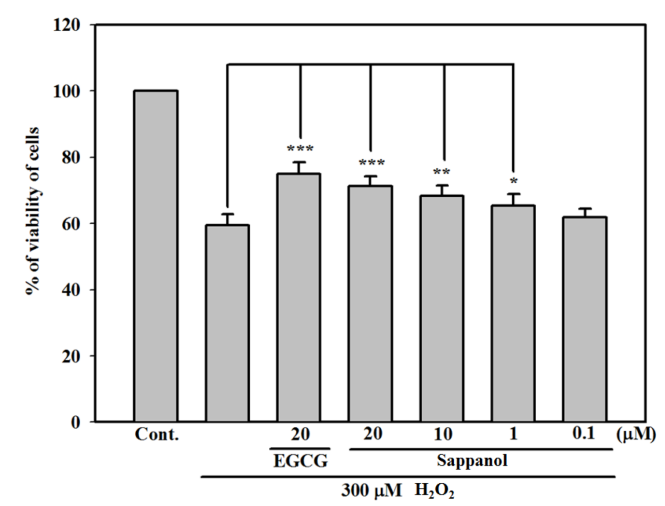

C

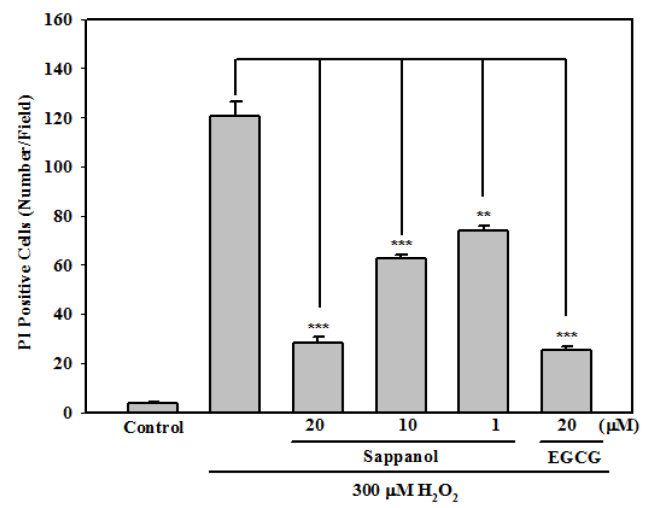

B
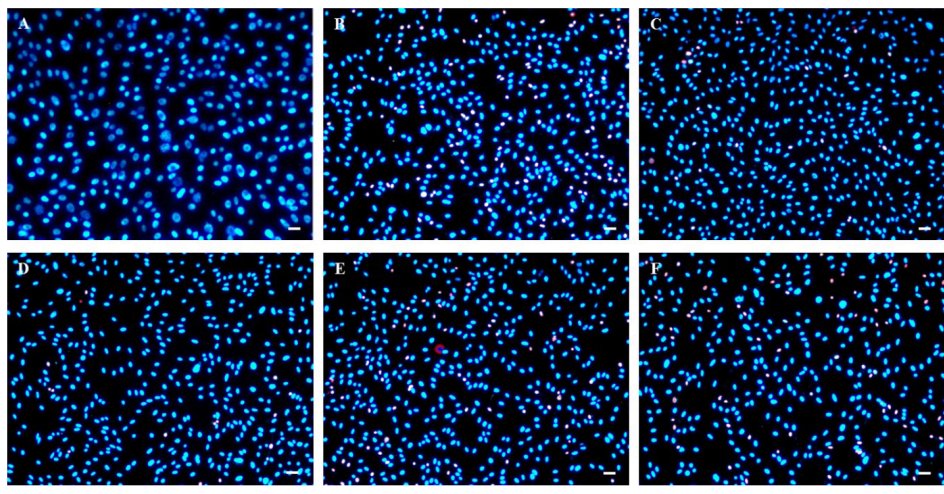

Fig. 2. (A) Effect of C. sappan on the viability of RGC-5 cells exposed to $300 \mu \mathrm{M} \mathrm{H}_{2} \mathrm{O}_{2}$ for $24 \mathrm{~h}$ as measured by the MTT assay. $0.2 \mathrm{mM}$ EGCG was used as a positive control. The results are mean values with error bars indicating \pm S.E.M. where $\mathrm{n}=5$ independent experiment $\left({ }^{*} \mathrm{P}<0.05,{ }^{* * P}\right.$ $\left.<0.01,{ }^{* * * \mathrm{P}}<0.001\right)$. (B) Representative fluorescence microscopy of $\mathrm{PI}$ (red) and Hoechst 33342 (blue) staining. a. Control RGC-5 cells in culture. b. $300 \mu \mathrm{M} \mathrm{H} \mathrm{H}_{2} \mathrm{O}_{2}$ treated RGC-5 cells in culture. c-e. Pre-treatment with sappanol (0.1 to $10 \mu \mathrm{g} / \mathrm{ml}$ concentration) followed by $\mathrm{H}_{2} \mathrm{O}_{2}$. f. Pre-treatment with EGCG $\left(0.2 \mathrm{mM}\right.$ concentration) followed by $\mathrm{H}_{2} \mathrm{O}_{2}$. Scale bar $=50 \mu \mathrm{m}$. (C) PI positive cells were counted using a cell counter under a fluorescence microscope at 100 times magnification and four representative images were used to estimate the percent of $\mathrm{Pl}$ positive cells of total cell numbers (Minimum 200 cells /well were counted). ${ }^{* * P}<0.01,{ }^{* * * P}<0.001$ versus control. 


\section{The effects of sappanol and brazilin on retinal cell death caused by $\mathrm{H}_{2} \mathrm{O}_{2}$}

As a an exogenous source of ROS, oxidative insult is known to cause significant molecular damage within cells and the peroxidation of lipids, which causes further damage to DNA, proteins, and lipids $(15,16)$. Sappanol and brazilin from C. sappan were tested for protective effects against $\mathrm{H}_{2} \mathrm{O}_{2}$-induced oxidative stress using RGC-5 cells (Fig. 2A). As shown in Fig. 2A, exposure of the RGC-5 cells to $300 \mu \mathrm{M} \mathrm{H}_{2} \mathrm{O}_{2}$ reduced cell viability by approximately $40 \%$. However, pre-treatment of the RGC-5 cells with sappanol significantly reduced the cytotoxic effect of $\mathrm{H}_{2} \mathrm{O}_{2}$ in a concentration-dependent manner (Fig. 2A).

In RGC- 5 cells, brazilin at a dose of $50 \mu \mathrm{M}$ was cytotoxic and produced a cell survival rate that was less than $50 \%$. However, at $20 \mu \mathrm{M}$ both compounds appeared to be safe for use, as indicated by cell survival rates greater than $80 \%$ (data not shown). These results show that sappanol protected RGC-5 cells from $\mathrm{H}_{2} \mathrm{O}_{2}$-induced oxidative damage in a concentrationdependent manner, and thus should be further studied as a treatment for oxidative stress-induced retinal cell death.

\section{Microscopic analysis of cell viability by propidium iodide (PI) and Hoechst 33342 double staining}

To verify the cell viability assay, microscopic analysis was performed using a Hoechst 33342/ propidium iodide (PI) double staining method (Fig. 2B). PI-positive cells were counted using a cell counter under a fluorescence microscope at 100x magnification, and 4 representative images were used to estimate the percentage of total cells that were PI-positive (a minimum of 200 cells/well were counted) as shown in Fig. 2B. Cells under the control condition displayed normal nuclear morphology with few red-stained nuclei. However, cells exposed to $\mathrm{H}_{2} \mathrm{O}_{2}$ showed numerous red-stained nuclei, which were thought to be apoptotic or necrotic cells. Importantly, the numbers of dead red-stained cells were clearly reduced in cultures treated with sappanol (Fig. 2B).

The effects of sappanol and brazilin on intracellular ROS levels In RGCs, $\mathrm{H}_{2} \mathrm{O}_{2}$-induced excessive $\mathrm{ROS}$ can cause cytotoxicity through the caspase-independent apoptotic pathway (9). To quantify intracellular ROS, 2', $7^{\prime}$ - dichlorofluorescein diacetate (DCFH-DA) was used as a radical probe in RGC-5 cells. Intracellular ROS levels were determined based on superoxide-sensitive DCF fluorescence, and were elevated by $\mathrm{H}_{2} \mathrm{O}_{2}$ and $\mathrm{H}_{2} \mathrm{O}_{2}+\mathrm{Fe}$ (II) oxidative insults. $\mathrm{H}_{2} \mathrm{O}_{2}$ and $\mathrm{H}_{2} \mathrm{O}_{2}+\mathrm{Fe}$ (II) oxidative insults increased ROS levels up to $170 \%$ and $230 \%$ respectively relative to the control cells. However, pre-treatment of the cells with sappanol, brazilin, or epigallocatechin gallate (EGCG) prior to $\mathrm{H}_{2} \mathrm{O}_{2}$ insult decreased ROS levels in a concentration-dependent manner (Fig. 3A and 3B). Sappanol, brazilin, and EGCG also decreased ROS levels after $\mathrm{H}_{2} \mathrm{O}_{2}+\mathrm{Fe}$ (II) insult in a concentration-dependent manner as shown in
A

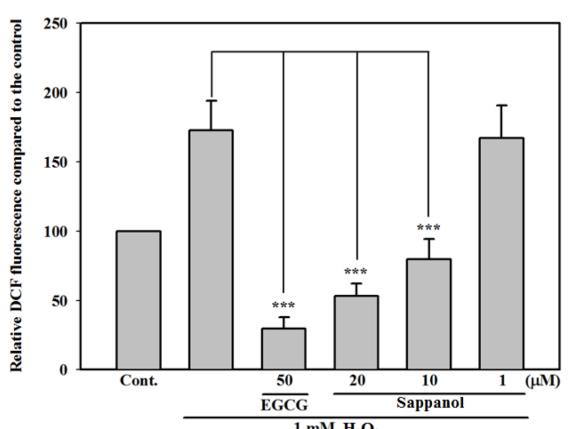

C

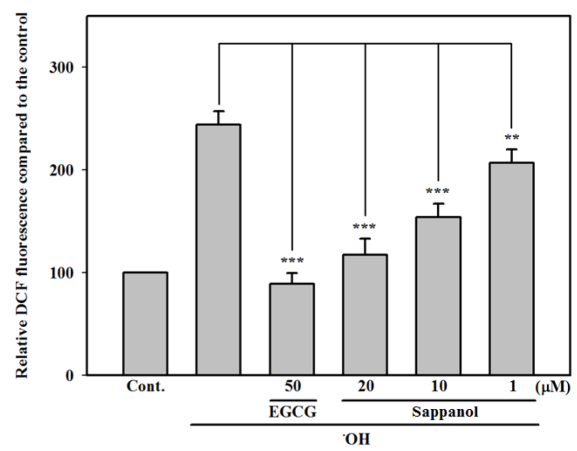

B

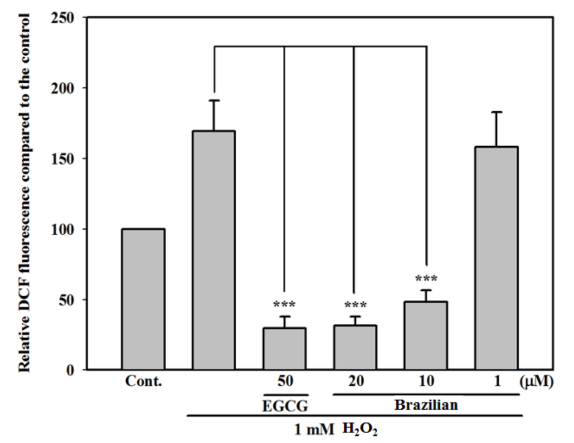

D

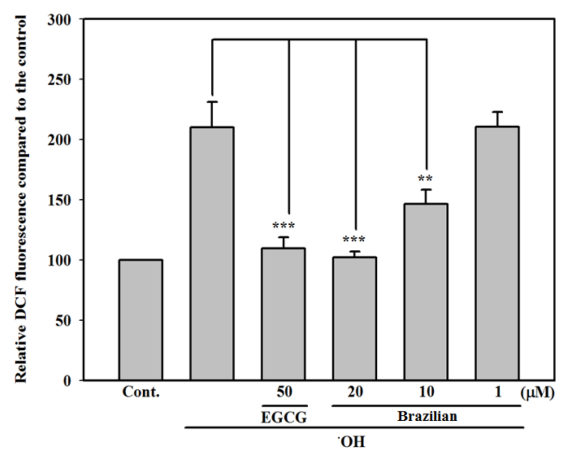

Fig. 3. Radical scavenging capacities of sappanol and brazilin against the production of various radical species $\left(\mathrm{H}_{2} \mathrm{O}_{2}\right.$, $\cdot \mathrm{OH})$ in RGC-5 cells. ROS production was stimulated with $\mathrm{H}_{2} \mathrm{O}_{2}$ at $1 \mathrm{mM}$ (A and $B$ ), or with $\mathrm{H}_{2} \mathrm{O}_{2}$ at $1 \mathrm{mM}$ plus ferrous perchlorate (II) at $100 \mu \mathrm{M}$ (C and D). Epigallocatechin gallate (EGCG) was used as a positive control. Results are mean values with error bars indicating \pm S.E.M. where $\mathrm{n}=3$. ${ }^{* * \mathrm{P}}<$ $0.01, * * * P<0.001$ versus control. 
Fig. 3C and 3D. These results show that sappanol and brazilin isolated from C. sappan attenuated ROS production caused by two different radical species.

\section{The effect of sappanol on MDA content}

ROS produce malondialdehyde (MDA), which is an end-product of lipid peroxidation, the hallmark of ROS-induced injury (17). To study the inhibitory effects of sappanol on lipid peroxidation, sodium nitropruside (SNP)-induced production of MDA was measured using a thiobarbituric acid reactive species (TBARS) assay in rat brain homogenates. MDA levels indicated that $20 \mu \mathrm{M}$ SNP increased lipid peroxidation compared to the untreated control group. However, sappanol inhibited the production of MDA in a concentration-dependent manner with an $\mathrm{IC}_{50}$ value of $8.59 \mu \mathrm{M}$ (Table 1). SNP-induced TBARS formation was dose-dependently attenuated by sappanol; however, its effect was not greater than that of positive control EGCG.

\section{The effects of sappanol and brazilin on apoptotic cell death caused by sodium azide}

Because of its redox potential, ROS generation was also examined in the context of the four-complex mitochondrial electron transport chain, of which complex IV is inhibited by sodium azide (SAZ). It has been demonstrated that antioxidants are not able to reverse this SAZ inhibition (18). Sappanol and brazilin were tested for protective effects against SAZ insult. In RGC-5 cells, exposure to $15 \mathrm{mM} \mathrm{SAZ}$ caused moderate reductions in cell viability. Interestingly, pretreatment with sappanol and brazilin did not inhibit cell death (data not shown). Therefore, in contrast to their effects on $\mathrm{H}_{2} \mathrm{O}_{2}$-induced oxidative stress in RGC-5 cells, compounds isolated from C. sappan did not protect complex IV of the mitochondrial electron chain.

\section{Conclusions}

Sappanol and Brazilin showed protective effects against oxidative stress-induced retinal cell death, and attenuated A2E photooxidation. Thus, these natural compounds isolated from $C$. sappan represent potential treatments for oxidative stress-induced retinal diseases. Further study will illuminate the mechanisms involved in these protective effects and the full neuroprotective abilities of these compounds.

\section{MATERIALS AND METHODS}

Materials and Methods are described in the online data supplement, available at http://www.bmbreports.org/.

\section{ACKNOWLEDGEMENTS}

The RGC-5 cells were kindly gifted by Alcon Research, Ltd. This work was financially supported by an intramural grant (2Z04381) from the Korea Institute of Science and Technology (KIST), Republic of Korea.

\section{REFERENCES}

1. Almasieh M, Wilson AM, Morquette B, Cueva Vargas JL and Di Polo A (2012) The molecular basis of retinal ganglion cell death in glaucoma. Prog Retin Eye Res 31, 152-181

2. Wein FB and Levin LA (2002) Current understanding of neuroprotection in glaucoma. Curr Opin Ophthalmol 13, 61-67

3. Osborne NN, Melena J, Chidlow G and Wood JP (2001) A hypothesis to explain ganglion cell death caused by vascular insults at the optic nerve head: possible implication for the treatment of glaucoma. Br J Ophthalmol 85, 1252 1259

4. Kim KA, Kang KD, Lee EH, Nho CW and Jung SH (2011) Edible wild vegetable, Gymnaster koraiensis protects retinal ganglion cells against oxidative stress. Food Chem Toxicol 49, 2131-2143

5. Levkovitch-Verbin $H$, Martin KR, Quigley HA, Baumrind LA, Pease ME and Valenta D (2002) Measurement of amino acid levels in the vitreous humor of rats after chronic intraocular pressure elevation or optic nerve transection. J Glaucoma 11, 396-405

6. Godley BF, Shamsi FA, Liang FQ, Jarrett SG, Davies S and Boulton M (2005) Blue light induces mitochondrial DNA damage and free radical production in epithelial cells. J Biol Chem 280, 21061-21066

7. Hockberger PE, Skimina TA, Centonze VE et al (1999) Activation of flavin-containing oxidases underlies light-induced production of $\mathrm{H}_{2} \mathrm{O}_{2}$ in mammalian cells. Proc Natl Acad Sci U S A 96, 6255-6260

8. Gaillard ER, Avalle LB, Keller LM, Wang Z, Reszka KJ and Dillon JP (2004) A mechanistic study of the photooxidation of $\mathrm{A} 2 \mathrm{E}$, a component of human retinal lipofuscin. Exp Eye Res 79, 313-319

9. Jung SH, Kim BJ, Lee EH and Osborne NN (2010) Isoquercitrin is the most effective antioxidant in the plant Thuja orientalis and able to counteract oxidative-induced damage to a transformed cell line (RGC-5 cells). Neurochem Int 57, 713-721

10. Ingkaninan $\mathrm{K}$, ljzerman AP, Taesotikult $\mathrm{T}$ and Verpoorte $\mathrm{R}$ (1999) Isolation of opioid-active compounds from Tabernaemontana pachysiphon leaves. J Pharm Pharmacol 51, 1441-1446

11. Xie YW, Ming DS, Xu HX, Dong H and But PP (2000) Vasorelaxing effects of Caesalpinia sappan involvement of endogenous nitric oxide. Life Sci 67, 1913-1918

12. Badami S, Moorkoth S, Rai SR, Kannan E and Bhojraj S (2003) Antioxidant activity of Caesalpinia sappan heartwood. Biol Pharm Bull 26, 1534-1537

13. Kijlstra A, Tian Y, Kelly ER and Berendschot TT (2012) Lutein: more than just a filter for blue light. Prog Retin Eye Res 31, 303-315

14. Yoon KD, Yamamoto K, Ueda K, Zhou J and Sparrow JR (2012) A novel source of methylglyoxal and glyoxal in retina: implications for age-related macular degeneration. PLoS One 7, e41309

15. Esterbauer $\mathrm{H}$ (1993) Cytotoxicity and genotoxicity of lipid-oxidation products. Am J Clin Nutr 57, 779S-785S; discussion 785S-786S 
16. Veal EA, Day AM and Morgan BA (2007) Hydrogen peroxide sensing and signaling. Mol Cell 26, 1-14

17. Dib M, Garrel C, Favier A, Robin V and Desnuelle C (2002) Can malondialdehyde be used as a biological marker of progression in neurodegenerative disease? J Neurol 249, 367-374

18. Ji D, Kamalden TA, del Olmo-Aguado $S$ and Osborne NN (2011) Light- and sodium azide-induced death of RGC-5 cells in culture occurs via different mechanisms. Apoptosis 16, 425-437

19. Xu P, Guan S, Feng R, Tang R and Guo D (2012) Separation of four homoisoflavonoids from Caesalpinia sappan by high-speed counter-current chromatography. Phytochem Anal 23, 228-231

20. Van Bergen NJ, Wood JP, Chidlow G et al (2009) Recharacterization of the RGC-5 retinal ganglion cell line.
Invest Ophthalmol Vis Sci 50, 4267-4272

21. Mosmann T (1983) Rapid colorimetric assay for cellular growth and survival: application to proliferation and cytotoxicity assays. J Immunol Methods 65, 55-63

22. Shimazawa $M$, Nakajima $Y$, Mashima $Y$ and Hara $H$ (2009) Docosahexaenoic acid (DHA) has neuroprotective effects against oxidative stress in retinal ganglion cells. Brain Res 1251, 269-275

23. Zhang B and Osborne NN (2006) Oxidative-induced retinal degeneration is attenuated by epigallocatechin gallate. Brain Res 1124, 176-187

24. Jung SH, Kang KD, Ji D et al (2008) The flavonoid baicalin counteracts ischemic and oxidative insults to retinal cells and lipid peroxidation to brain membranes. Neurochem Int 53, 325-337 